\title{
LIQUIDITY RISK ON BANKING INDUSTRY: COMPARATIVE STUDY BETWEEN ISLAMIC BANK AND CONVENTIONAL BANK IN INDONESIA
}

\author{
Harjum Muharam \& Hasna Penta Kurnia*
}

\begin{abstract}
Abstrak: Risiko Likuiditas pada Perbankan: Studi Banding Antara Bank Syariah dan Bank Konvensional di Indonesia. Bank konvensional dan syariah kurang lebih memiliki risiko sama. Oleh karena itu perlu pengamatan lebih lanjut untuk mengendalikan risiko likuiditas mereka. Studi ini mengkaji pengaruh CAR, rasio profitabilitas, NIM, kesenjangan likuiditas, dan RLA milik risiko likuiditas di industri perbankan. Analisis statistik menyimpulkan bahwa terdapat pengaruh negatif dan signifikan dari CAR dan ROE terhadap risiko likuiditas pada bank konvensional, sementara ROA dan RLA berpengaruh positif dan signifikan. Dalam bank syariah, dampak positif dan signifikan dari NIM dan ROE terhadap variabel dependen, sedangkan kesenjangan likuiditas dan RLA memiliki pengaruh signifikan.
\end{abstract}

Kata Kunci: bank konvensional, bank syariah, risiko likuiditas

\begin{abstract}
Liquidity Risk on Banking Industry: Comparative Study Between Islamic Bank and Conventional Bank in Indonesia. Conventional and Islamic banks approximately are similar in risk summary. Therefore it needs further observations to control their liquidity risk. This study investigates the influence of CAR, profitability ratios, NIM, liquidity gaps, and RLA belongs to liquidity risk on banking industry. The statistical analysis concluded that there are negative and significant influence of CAR and ROE to liquidity risk on conventional banks, while ROA and RLA have positive and insignificant effect. In Islamic banks, a positive and significant impact of NIM \& ROE to dependent variable, whereas liquidity gaps and RLA have insignificant affect.
\end{abstract}

Keywords: conventional banks, Islamic banks, liquidity risk

Received: 4th December 2012, revised: 10th May 2013, accepted: 16th May 2013.

* Faculty of Economic and Business, Diponegjoro University. Jl. Prof. Soedharto, Tembalang, Semarang, Jawa Tengah. E-mail: harjum_muharam@yahoo.co.id 


\section{Introduction}

In daily business transactions, bank has some risk as consequences caused by their activities. There will be no bank if there is no braveness to take risk. There are several risks that must be considered by banks, for example: market risk, operational risk, legal risk, compliance risk, credit risk, and liquidity risk. One of crucial risk is liquidity risk that comes from the mismatch timing between cashinflow and cashoutflow. This lack outcome from cash that hopefully to be invested in credit loans or outcome from deficit cash that needed to meet their short-term obligations ${ }^{1}$. Conventional banks adopt interest system which it can be used to fulfill the cash needed, on the other hand this system is forbidden in Islamic banks so they can not spend the profit of loans to cover their maturitity dates.

Banks are considered in liquid circumstances when they go through some requirements, bank has some liquid instruments and these are equal with the amount of liquidity needs. Bank has the ability to obtain liquidity by creating or converting cash, and bank has less liquidity than needed. When bank meets the standard, this regulated entities has less troubled condition. It can be assumed the liquidity risk can be pushed.

Nowadays, many countries adopt two systems banking which are conventional and Islamic or sharia banking system. Similar in Indonesia, many banks already have these kind of systems. The first established Islamic bank is Muammalat Indonesia Bank that has started their operation in 1992 and it was followed by other banks. Today, sharia bank is an alternative for customers especially moeslems who disagree with interest system that forbbiden in Islam.

This study aims to analyze the influence of CAR, ROA, ROE, NIM, liquidity gaps, and RLA to liquidity risk between conventional and Islamic banks in Indonesia.

\section{Theoritical Framework and Hypothesis Formula}

The concept of liquidity lies at the heart of commercial banking and the mana-gement of its funds. It represents one of the crucial risk in banking industry. Liquidity risk is the possibility of loss, generating the cash needed to meet short term maturity dates included. The banking industry requires liquidity be given important consideration in funds management ${ }^{2}$. The proxie that can be used to measure this risk by ratio between cash and total assets. According to

\footnotetext{
${ }^{1}$ Anas \& Mounira, "Managing Risk and Liquidity in an Interest Free Banking Framework: The Case of the Islamic Banks", International Journal of Business and Management, 2008.

${ }^{2}$ Haslem, Bank Funds Management, (Virginia: Reston Publishing Company 22090, 1984).
} 
Haslem, there are various strategies for bank to obtain liquidity: (a) holding adequate cash assets, (b) converting assets to cash, (c) borrowing. The ratio between cash and total assets describes how far the assets on banks can be converted to be cash to cover their liquidity risk. Some determinants factors that may influence liquidity risk are Capital Adequacy Ratio (CAR), Return On Assets (ROA), Return On Equity (ROE), Net Interest Margin (NIM), liquidity gaps, Risky Liquid Assets to Total Assets (RLA).

CAR is the ratio which is used to measure capital adequacy to support the bank owned assets that contain or produce risk, such as loan ${ }^{3}$. ROA measures the ability of bank management in acquiring and managing the profitability of the bank's overall business effeciency ${ }^{4}$. ROE measures the ability of the company in making a profit available to shareholders ${ }^{5}$. NIM is the ratio of interest income that is received from loans made to average earning assets ${ }^{6}$. Liquidity gaps are the disparities between assets and liabilities that cause liquidity risk ${ }^{7}$. RLA is the ratio that is used to measure how big the risky liquid assets of banks which can be converted to cash by selling them in low price ${ }^{8}$.

First, the influence of car to liquidity risk. CAR is the ratio that shows how far the risky bank assets (loans, investments, securities) financed of the bank's own capital funds ${ }^{9}$. Greater CAR means banks have big capital which it means the capital can be used to cover their maturity dates and bank will have less trouble or risky situation. The previous research conducted by Akhtar ${ }^{10}$ and Anjum Iqbal ${ }^{11}$ shows that CAR has positive influence to liquidity risk. In contrary, greater CAR means banks have big capital which it means the capital can be used to cover their maturity dates and bank will have less trouble or risky

${ }^{3}$ Dendawijaya, Manajemen Perbankan, (Jakarta: PT. Ghalia Indonesia, 2005).

${ }^{4}$ Mahrinasari, "Liquidity Risk Management: A Comparative Study between Conventional and Islamic of Pakistan", USA: Global Journal of Management and Business Research, 2003.

${ }^{5}$ Hanafi \& Halim, Analisis Laporan Keuangan, (Yogyakarta: YKPN, 2013).

${ }^{6}$ Hasibuan, Dasar- Dasar Perbankan, (Jakarta: PT. Bumi Aksara, 2005).

${ }^{7}$ Bessis, Risk Management in Banking, $2^{\text {nd }}$ Edition, 2003.

${ }^{8}$ C.-H. Shen, C.-J. Kuo, and H.-J. Chen, "Determinants of Net Interest Margins in Taiwan Banking Industry", Taiwan: Journal of Financial Studies, Vol. 9, 2001, p. 47-83.

${ }^{9}$ C.-H. Shen, C.-J. Kuo, and H.-J. Chen, "Determinants of Net Interest Margins in Taiwan Banking Industry", III.

${ }^{10}$ M. Akhtar, K. Ali, \& S. Sadaqat, "Liquidity Risk Management: A Comparitive Study between Conventional and Islamic Bank of Pakistan", Lahore: Interdisciplinary Journal of Research in Business, 2001.

${ }^{11}$ Anjum Iqbal, "Liquidity Risk Management: A Comparative Study between Conventional and Islamic of Pakistan”, USA: Global Journal of Management and Business Research, 2012. 
condition. Based on this argument, the hypothesis formulated as follows: $\mathrm{H1}$ : CAR has negative influence to liquidity risk.

Second, the influence of ROA to liquidity risk. ROA is the ratio to mea-sure the ability of bank management in acquiring and amanging the profitability of the bank's overall busines effeciency ${ }^{12}$. Greater ROA means banks have good revenue that it can be used to cover their short term obligation. It means banks will have less trouble or risky situation. The previous research conducted by Shen ${ }^{13}$ and Al-Khouri ${ }^{14}$ shows this ratio has negative and significant impact to liquidity risk. Based on this argument, the hypothesis formulated as follows: $H 2$ : ROA has negative influence to liquidity risk.

Third, the influence of ROE to liquidity risk. ROE decribes the ability of the company in making a profit to shareholders ${ }^{15}$. According to Shen et al., banks that have higher liquidity risk or larger gap lack on cheap fund, and thus they should use liquid assets from external funding to meet the demand of fund. This external source of fund sometimes requires higher cost and it will decrease profitability (ROE). In contrary, when banks have higher ROE means they have big earnings that can be used to back up their short term obligations and banks will have less trouble or risky condition. The research by Shen et al. shows ROE has negative impact to liquidity risk ${ }^{16}$. Based on this argument, the hypothesis formulated as follows: H3: ROE has negative influence to liquidity risk.

Fourth, the influence of NIM to liquidity risk. NIM is the ratio of interest income that is received from loans made to average earning assets ${ }^{17}$. Greater of this ratio means banks have higher interest net income that can be used to meet their maturity dates. It makes banks will have less possibilities in trouble. The previous research by Sharma and Gounder found that NIM had negative impact to liquidity risk ${ }^{18}$. Based on this argument, the hypothesis formulated as follows: H4 : NIM has negative influence to liquidity risk.

Fifth, the influence of liquidity gaps to liquidity risk. Liquidity gaps are the disparities between assets and liabilities that cause liquidity risk ${ }^{19}$. Greater of

${ }^{12}$ Anjum Iqbal, "Liquidity Risk Management", p. Iv.

${ }^{13}$ Anjum Iqbal, "Liquidity Risk Management", p. Viii.

${ }^{14} \mathrm{R}$. al-Khouri, "Assessing the Risk and Performance of the GCC Banking Sector", Qatar: International Research Journal of Finance and Economics, 2011.

${ }^{15} \mathrm{R}$. Al-Khouri, "Assessing the Risk and Performance of the GCC Banking Sector", p. V.

${ }^{16} \mathrm{R}$. Al-Khouri, "Assessing the Risk and Performance of the GCC Banking Sector", p. viii.

${ }^{17}$ R. al-Khouri, "Assessing the Risk and Performance of the GCC Banking Sector", p. vi.

${ }^{18}$ P. Sharma \& N. Gounder, "Determinants of Bank Net Interest Margins in a Small Island Developing Economy: Panel Evidence from Fiji", Griffith University: Department of Accounting, Finance and Economics, Discussion Papers in Finance, 2011.

${ }^{19}$ P. Sharma \& N. Gounder, "Determinants of Bank Net Interest Margins", p. vii. 
liquidity gaps means banks have higher liquidity risk and the vice versa, as lower as this ratio gives a sign to banks having a lower risks. Based on this argument, the hypothesis formulated as follows: H5 : Liquidity gaps have positive influence to liquidity risk.

Sixth, the influence of RLA to liquidity risk. RLA is the ratio that is used to measure how big the risky liquid assets of banks which can be converted to cash by selling them in low price ${ }^{20}$. Eventhough on the way converting this assets, banks will get difficulties that is called credit freeze. In their research, Shen et al. found that RLA has negative impact to liquidity risk. Based on this argument, the hypothesis formulated as follows: H6: RLA has negative influence to liquidity risk.

Seventh, comparison liquidity risk between conventional bank and Islamic bank. The red line that makes some differences between conventional and Islamic banks is on their reward to customers. Conventional bank adopts interest system to give profit to their customers which is forbidden in Islamic bank. On the other hand, Islamic bank adopts profit sharing system to give profit to their customers. Interest system is more fluctuative and more risky than profit sharing system. It will give different influence on their liquidity risk. Based on this argument, the hypothesis formulated as follows: $H 7$ : There is difference that caused by liquidity risk between Conventional Bank and Islamic Bank.

\section{Research Method}

Dependent variable in this study is liquidity risk that is measured by ratio between cash and total assets ${ }^{21}$. Independent variables in this research are CAR, ROA, ROE, NIM, liquidity gaps, and RLA. CAR is the ratio between bank capital and total average assets by risk. ROA is the ratio between earning after tax to total assets. ROE is the ratio between earning after tax to total equity. NIM is the ratio between net interest income to earning assets. Liquidity gaps is the natural logarithma from assets minus liabilities. RLA is the ratio between risky liquid assets to total assets.

Population in this research are conventional and Islamic banks in Indonesia that are listed in Indonesia Banking Directory period 2007-2011 which are 43 conventional banks and 4 Islamic banks. The selection of samples uses purposive sampling method. The criterion of sampling based on: (1) Conventional banks and Islamic banks that display their financial statement period 20072011 and available in Indonesian Banking Directory. (2) Conventional banks and

\footnotetext{
${ }^{20}$ P. Sharma \& N. Gounder, "Determinants of Bank Net Interest Margins", p. viii.

${ }^{21}$ P. Sharma \& N. Gounder, "Determinants of Bank Net Interest Margins", p. x.
} 
Islamic banks that display their financial statement and finance ratio completly which are suitable with the ratios on this research. ((3) Conventional banks and Islamic banks that have no negative post in every finance ratio during period research.

Based on the purposive sampling, there are three conventional banks and three Islamic banks that are selected as samples, that can be seen in Table 1 in below:

Table 1: The Sample of Research

\begin{tabular}{cc}
\hline Conventional Bank & Islamic Bank \\
\hline Permata Bank & Mandiri Sharia Bank \\
CIMB Niaga Bank & Mega Sharia Bank \\
Bukopin Bank & Muammalat Indonesia Bank \\
\hline
\end{tabular}

Source : Indonesia Banking Directory

The data used in this research are financial statements of conventional and Islamic banks period 2007-2011. Multiple regression method with ordinary least squared estimation is used for analyzing data. Based on estimation results, t-test is conducted in hypothesis testing. Chow test is used in comparing liquidity risk between Islamic bank and conven-tional bank by analyzing structural break on the liquidity risk behavior. Empirical model of this research as follows:

$$
\begin{array}{ll}
\mathrm{Y}=\mathrm{a}+\mathrm{b}_{1} \mathrm{X}_{1}+\mathrm{b}_{2} \mathrm{X}_{2}+\mathrm{b}_{3} \mathrm{X}_{3} & +\mathrm{b}_{4} \mathrm{X}_{4}+\mathrm{b}_{5} \mathrm{X}_{5}+\mathrm{b}_{6} \mathrm{X}_{6}+\mathrm{e} \\
\text { Definition : } \quad \mathrm{Y} & =\text { Liquidity risk } \\
\mathrm{a} & =\text { Constanta } \\
\mathrm{b}_{1}-\mathrm{b}_{6} & =\text { regression coefficient of independent } \\
& \text { variables } \\
\mathrm{X}_{1} & =\text { Capital Adequacy Ratio } \\
\mathrm{X}_{2} & =\text { Return On Assets } \\
\mathrm{X}_{3} & =\text { Return On Equity } \\
\mathrm{X}_{4} & =\text { Net Interest Margin } \\
\mathrm{X}_{5} & =\text { Liquidity Gaps } \\
\mathrm{X}_{6} & =\text { Risky Liquid Assets to Total Assets } \\
\mathrm{e} & =\text { error }
\end{array}
$$


The formula of Chow-test is :

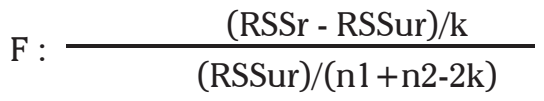

Definition : $\quad \begin{array}{ll}\text { RSSr } & =\text { Restricted residual sum of squares } \\ \text { RSSur } & =\text { unRestricted residual sum of squares } \\ \mathrm{k} & =\text { sum of parameter that estimated } \\ \mathrm{n} & =\text { sum of observation }\end{array}$

\section{Result and Discussion}

Table 2 below shows the result of descriptive analysis that consist of number of samples $(\mathrm{N})$, the sample average (mean), maximum value, minimum value and stan-dard deviation for each variable. All that items descript sample characteristics that are used in this study ${ }^{22}$.

Table 2: The Result of Descriptive Analysis

\begin{tabular}{ccccc}
\hline Variable & \multicolumn{2}{c}{ Conventional Bank } & \multicolumn{2}{c}{ Islamic Bank } \\
\hline & Mean & Std. Deviation & Mean & Std. Deviation \\
\hline CAR & 14,0013 & 1,86767 & 12,5848 & 1,86427 \\
\hline ROA & 1,9535 & 0,45587 & 2,2483 & 1,09908 \\
\hline ROE & 18,8857 & 3,53752 & 37,72 & 18,77933 \\
\hline NIM & 5,4208 & 0,98297 & 8,3008 & 3,53042 \\
\hline LG & 15,91 & 0,76638 & 15,8896 & 0,9231 \\
\hline RLA & 2,7932 & 0,72261 & 3,3883 & 1,53958 \\
\hline
\end{tabular}

Source: The secondary data is processed

Based on Table 2 is known that the sample average (mean) on Islamic banks is bigger than conventional banks in variable ROA, ROE, NIM, and liquidity gaps. Whereas CAR on conventional banks (14\%) is bigger than Islamic banks $(12,58 \%)$. It means conventional banks have more ability to control their adequacy capital than Islamic banks. Other variables Islamic banks are higher than conventional banks, those can be seen from ROA (2,25\% to 1,9\%), ROE ( $37,72 \%$ to $18,88 \%)$, NIM ( $8,3 \%$ to $5,42 \%)$, and RLA (3,38\% to $2,79 \%)$. Both conventional and Islamic banks can control their capital that are needed and

${ }^{22}$ Imam Ghozali, Aplikasi Analisis Multivariate Dengan Program SPSS, (Semarang: Publisher of Diponegoro University, 2012). 
generating their earnings. Both capital and earning can be used to meet their short-term obligations and the banks will less possibility in troubled situation.

Based on assumption classic tests (normality test, heterocedasticity test, multi-colinearity test, and autocorrelation test) resulted that data are normally distributed, because the significance value of Kolmogorov-Smirnov test is bigger than the significance level at 0,05 both in conventional banks $(0,341)$ and Islamic banks $(0,185)$. In addition, there are no heterocedasticity, multicolinearity, and autocorrelation in the regression model so this model is suitable to predict liquidity risk that is measured by cash to total assets which are influenced by CAR, profitability ratios, NIM, LG, and RLA.

Tabel 3

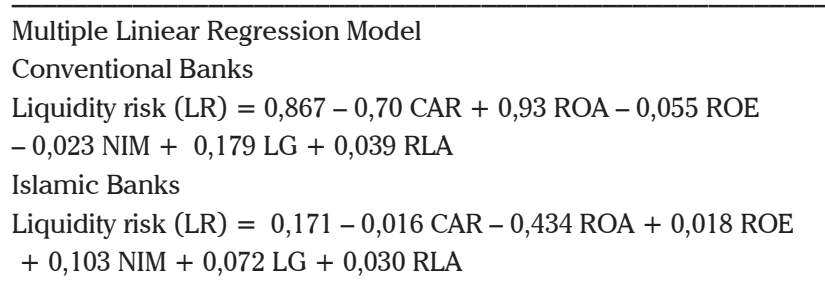

Source: The secondary data is processed

Whereas, based on goodness of fit of hypothesis testing (coefficient determination, f-test, and t-test) shows the independent variables CAR, ROA, ROE, NIM, and LG, have a strong effect to liquidity risk. In contrary, RLA has a weak effect to the dependent variable.

The first hypothesis is accepted in conventional banks because these banks have negative and significant effect to dependent variable, whereas in Islamic banks is unaccepted because CAR has negative and insignificant effects to it. The significance value is 0,014 smaller than 0,05 in first model and in second model is 0,732 bigger than significance level. Conventional banks already have good ability to control their capital from the risky possibility or losing their business. It can also be assumed that they have funds to cover their risk of loss from the capital. This finding support previous study conducted by Shen and AlKhouri that was discussed before. Whereas Islamic banks do not use the capital to cover their short-term obligations, but the profit. 
Table 4: The Result of Hypothesis Testing

\begin{tabular}{lcccc}
\hline \multirow{2}{*}{ Variable } & \multicolumn{2}{c}{ Conventional Banks } & \multicolumn{2}{c}{ Islamic Banks } \\
\cline { 2 - 5 } & $\begin{array}{c}\text { Standardized } \\
\text { Coefficients }\end{array}$ & $\begin{array}{c}\text { Significance } \\
\text { Value }(\alpha=5 \%)\end{array}$ & $\begin{array}{c}\text { Standardized } \\
\text { Coefficients }\end{array}$ & $\begin{array}{c}\text { Significance } \\
\text { Value }(\alpha=5 \%)\end{array}$ \\
\hline CAR & $-2,554$ & 0,014 & $-0,356$ & 0,723 \\
\hline ROA & 0,527 & 0,600 & $-3,419$ & 0,001 \\
\hline ROE & $-2,886$ & 0,006 & 2,634 & 0,011 \\
\hline NIM & $-0,329$ & 0,744 & 3,463 & 0,001 \\
\hline LG & 2,008 & 0,050 & 0,454 & 0,652 \\
\hline RLA & 0,490 & 0,626 & 0,474 & 0,638 \\
\hline
\end{tabular}

Source: The secondary data is processed

The second hypothesis is accepted in Islamic banks because these banks have negative and significant effects to dependent variable, whereas in conventional banks is unaccepted because ROA has positive and insignificant effects to it. Islamic banks have good ability in generating earnings from the assets, and it can be used to cover their short term maturity dates so banks have less trouble situation. Whereas in conventional banks, its variable has positive and insignificant effects to dependent variables. It is because these banks use their equity to cover their maturity dates. It makes the banks can use their assets to generate earnings. Previous studies conducted by Tafri and Akhtar showed the same result as same as this study. Economically we concluded that Islamic banks use profit in managing their liquidity risk and conventional banks use their capital.

The third hypothesis is accepted in conventional banks. ROE has negative and significant effects to dependent liquidity risk. On the other hand, in Islamic banks is unaccepted. Conventional banks have good ability in generating earnings from the equity and it can be used to cover their short term maturity dates so banks have less trouble situation. Whereas in Islamic banks, its variable has positive and significant effects to liquidity risk. It is because these banks use their assets to cover their maturity dates. It makes the banks can use their equity to generate earnings. This finding supported previous research conducted by Anjum Iqbal that found that ROE has positive and significant effects to liquidity risk.

The fourth hypothesis is unaccepted in both models. In conventional banks, NIM has negative and insignificant effect to liquidity risk. Whereas in Islamic banks, NIM has positive and significant effects to dependent variable. Conventional banks have good ability in generating net interest income from loans, and it can be used to cover their short term maturity dates so banks have 
less trouble. Its finding is supported by the research of Sharma and Gounder that found that NIM has negative influence to liquidity risk. Whereas in Islamic banks, its variable has positive and significant effects to dependent variables. Its mean that the higher the NIM the higher liquidity risk. In Islamic bank as a consequence of profit sharing system, the more profit that company can rise from operation the more cash must be distributed to the fund owners.

The fifth hypothesis is accepated in conventional banks because LG has negative and significant effects to dependent variable, whereas in Islamic banks is unaccepted because this ratio has positive and insignificant effects to liquidity risk. In conventional banks, it shows that the gap between assets and liabilities is liniear and it influences on liquidity risk. This bank can not control yet their risk by using assets therefore it is needed to manage the gap. Whereas Islamic banks can not either yet predicting the upcoming risk.

The sixth hypothesis is unaccepated in both models. It is because RLA has positive and insignificant effects to liquidity risk. Both banks use their risky liquid assets that can be converted to cash to fulfill their short-term obligations. Eventhough on colaterezing this assets they can meet some difficulties such as credit freeze.

Table 5: The Result of Chow-Test

\begin{tabular}{lccc}
\hline & Conventional Banks & Islamic Banks & Both Banks \\
\hline Residual Value & 7,316 & 20,769 & 35,148 \\
\hline $\mathrm{N}$ & 60 & 60 & 120 \\
\hline Chow Test $(\mathrm{F}$ calculated) & \multicolumn{4}{c}{4,115} \\
\hline $\mathrm{F}$ table $(\mathrm{k}=6 ; \mathrm{df}=98)$ & 2,46 \\
\hline
\end{tabular}

Source: The secondary data is processed

The seventh hypothesis can be accepted. It is because from the result of Chow-test which $\mathrm{F}$ calculated value is obtained at 4,115 while the value of $\mathrm{F}$ table is 2,46 . It suggests that there is a structural break in liquidity risk between conventional and Islamic bank. This finding proof the statement that difference system between conventional and Islamic bank rise difference behavior of risk. Conventional bank adopts interest system to give profit to their customers. The bank has fixed cost of fund and it is not depend on profit that was earned. On the other hand, Islamic bank adopts profit sharing system to give profit to their customers. This condition make interest system is more risky than profit sharing system. So, conventional banks face higher liquidity risk than Islamic banks from their business daily transaction. 


\section{Closing Remarks}

Nowadays, due to global economic system, both conventional and Islamic banks should be aware of the potential of liquidity risk. Its study examines liquidity risk through a comparative study between conventional and Islamic banks in Indonesia from the period 2007-2011. The above results show the fitness of both models 1 and 2 at F-statistic of 4,209 and 5,684 at 5\% significance level. Its point out that both models are good fit. Based on the result of hypothesis testing, independent variables that have negative and significant effects are CAR and ROE in conventional banks. Whereas in Islamic banks, ratio that has same effect is ROA. It means conventional banks have good ability to control their capital and generate earnings by their equity that can be used to meet their short term obligations. In contrary, Islamic banks have good ability to generate earnings by their assets. The result of Chow-test shows there is a difference influence of independent variables to liquidity risk between both models.

The strength of this study compared from previous study is the data used which are more longer and up-to date (2007-2011). The influence of CAR, ROA, ROE, NIM, LG, and RLA to liquidity risk make some differences between conventional and Islamic banks. The writer mention the function of its research to the bank management to well control their liquidity risk, by learning the pattern of the risk and economic circumtances. It is expected they will know the risk faced by them, and the possibility in trouble can be pushed. Banks expected to estimate accurately the short-term demand of liquidity especially for undpredictable demand one. ALCO on these bank should make strategies to submit the liquidity principles in cooperation.

The limitation of this study are the number of banks samples which are few number so there are still companies outside of the object research. Based on adjusted R2 value, there are still other variables that can explain but they are not included in this study. The future studies might increase the number of companies samples as the research objects and should add variables that may effect the liquidity risk. As a matter of fact, further research should not be limited on banking industry only but should also be extended on others indutries. []

\section{Bibliography}

Akhtar, M., Ali, K., \& Sadaqat, S., "Liquidity Risk Management: A comparitive study between Conventional and Islamic Bank of Pakistan", Lahore: Interdisciplinary Journal of Research in Business, 2011. 
Al-Khouri, R., "Assessing the Risk and Performance of the GCC Banking Sector", Qatar: International Research Journal of Finance and Economics, 2011.

Anas, E., \& Mounira, B.A., "Managing Risk and Liquidity in an Interest Free Banking Framework: The Case of the Islamic Banks". International Journal of Business and Management, 2008.

Bessis, Joel, "Risk Management in Banking", $2^{\text {nd }}$ Edition, 2002.

Dendawijaya, Manajemen Perbankan, Jakarta: PT. Ghalia Indonesia, 2003.

------------, Manajemen Perbankan, Jakarta: PT. Ghalia Indonesia, 205.

Ghozali, Imam, Aplikasi Analisis Multivariate dengan Program SPSS, Semarang: Publisher of Diponegoro University, 2006.

Hanafi, Mamduh \& Halim, Abdul, Analisis Laporan Keuangan, Yogyakarta: YKPN, 2003.

Hasibuan, Malayu, Dasar-dasar Perbankan, Jakarta: PT. Bumi Aksara, 2005.

Haslem, A., John, Bank Funds Management, Reston, Virginia: Reston Publishing Company, 22090, 1984.

Iqbal, Anjum, "Liquidity Risk Management: A Comparative Study between Conventional and Islamic of Pakistan", USA: Global Journal of Management and Business Research, 2012.

Mahrinasari, "Pengelolaan Kredit pada Bank Perkreditan Rakyat di Kota Bandarlampung", Economics and Business Faculty, 3/8, Universitas Lampung, Lampung, 2003.

Sharma, P. \& Gounder, N., "Determinants of bank net interest margins in a Small Island Developing Economy: Panel Evidence from Fiji. Griffith University, Department of Accounting, Finance and Economics. Discussion Papers in Finance: 2011.

Shen, C.-H., Kuo, C.-J., and Chen, H.-J., "Determinants of Net Interest Margins in Taiwan Banking Industry", Taiwan: Journal of Financial Studies, Vol. 9, 2001. 